\title{
Influence of Omega-3 and Green Tea Extract on Alcohol-Induced Liver Injury in Rats
}

\author{
Ridha Hassan Hussein \\ Department of Biology \\ College of Science \\ University/Sulaimani \\ Sulaimani, Iraq \\ Ridha.hussein@univsul.edu.iq
}

\author{
Zana Hassan Ibrahim \\ Department of Biology \\ College of Science \\ University/Raparin \\ Sulaimani, Iraq \\ zana.ibrahim@ raparinuni.org
}

\begin{abstract}
Drinking alcoholic beverages recently is common in many parts of the world, liver is a principal organ that involved in toxic effects of alcohol and it remains a serious health problem globally. Fatty liver (steatosis) was induced in male albino rats by alcohol $40 \%$ orally $(3.76 \mathrm{gm} / \mathrm{kgm} \mathrm{BW} /$ day) for the period of 4 weeks, then green tea extract (GTE) and omega-3 (OMG-3) fish oil were used as treatments for improvement and investigating their comparison potential role for the next 4 weeks. At the end of the experiment, the rats were fasted overnight, blood samples through the cardiac puncture and liver organ were collected for biochemical and histopathological analysis respectively. Biochemical parameters including: lipid profiles: (total cholesterol (TC), triglycerides (TG), high density lipoprotein-cholesterol (HDL-C) and low density lipoprotein-cholesterol (LDLC), serum malondialdehyde (MDA), liver function tests (LFT): (Serum albumin (ALB), serum total protein (TP), total serum bilirubin (TSB), serum alkaline phosphatase (ALP), serum alanine aminotransferase (ALT), and serum aspartate aminotransferase (AST) and finally hepatic histological changes were also investigated. Alcoholic rats were associated with significant elevation $(P<0.05)$ in the levels of serum $T C, T G, L D L-C, M D A, T S B, A L T, A S T$ and $A L P$, whereas the levels of serum HDL-C and TP significantly $(P<0.05)$ decreased with no significant change (P>0.05) of serum ALB level. treatment of alcohol-fed rats with GTE and OMG-3 oil either alone or in their combination have significant role $(P<0.05)$ in lowering the injury effects of alcohol evidenced by reversing the results obtained on serum lipid profiles, MDA, LFTs and hepatic histological changes after their treatments during the amelioration study. Ethanol consumption impaired hepatic functions, disturbed lipid metabolism, induced hyperlipidemia and increased oxidative stress. Aqueous extracts of GT and OMG-3 oil significantly improved alcohol-induced liver injury through improvement of serum markers of hepatic injury, their hypolipidemic actions and hepatic histologic recovery. Co-treatments of $G T+O M G-3$ have more protective effect or faster progression against ALD than their treatments alone.
\end{abstract}

Keywords: Alcohol, liver injury, ALD, Green tea, Omega-3.

\section{INTRODUCTION}

The alcohol-induced liver injury is one of the most common cause of liver diseases worldwide [1], most widely diagnosed forms are alcoholic fatty liver; alcoholic hepatitis and alcoholic cirrhosis [2].

The occurrence of alcoholic liver disease (ALD) is mediated by many mechanisms such as oxidative stress, acetaldehyde, hypoxia, and membrane alterations [3]. Omega-3 fatty acids are a family of polyunsaturated fatty acids (PUFA) [4], Eicosapentaenoic acid (EPA) and docosahexaenoic acid (DHA) considered the biologically important long-chained omega-3 PUFA, are found in large amounts in fish oil [5], they are integral components of the phospholipid bilayer in neuronal cell membranes, making them relevant to membrane physiology and neurotransmission [6]. Green tea is a beverage consumed worldwide, useful in the prevention of pro-oxidative states mediated by the formation of free radical species in different pathological situations [7].

\section{LITERATURE REVIEW}

Alcohol as a psychophysical and mood-altering agent is one of the oldest and most widely used on Earth. Although there are some beneficial aspects of moderate consumption of alcohol such as anxiolysis and vasodilation, chronic ethanol consumption is significantly implicated in the pathogenesis of a variety of disorders, including ALD [8].

World Health Organization (WHO) in 2005 reported that approximately 2 billion people consume alcohol worldwide and about 76 million of them are suffering from alcohol consumption disorders [9], and Europe is the heaviest drinking region in the world, over $20 \%$ of the European population aged $\geq 15$ reported heavy episodic drinking (five or more drinks on one occasion, or $50 \mathrm{~g}$ alcohol) at least once a week [10].

In the highly developed countries two-thirds of adults use alcohol. After heart disease and cancer alcoholism and alcohol-related diseases constitute the third largest health problem in the USA, affecting over 10 million people and causing about 200,000 deaths each year, 7.9 deaths $/ 100000$ in the USA and other developed 
countries [10].

Alcohol is metabolized in the liver, for this reason, the liver is especially vulnerable to alcohol-induced injury such as fatty liver, hepatitis, fibrosis, cirrhosis and hepatocellular carcinoma [11]. Both alcohol and its primary metabolites diminish or impair the hepatic antioxidant homeostasis, and the repeated incidences of these phenomena cause oxidation of cellular lipids, proteins, and DNA, and then finally leading to hepatic cell injury [12].

It is well known that only a small proportion of heavy drinkers develop the advanced form of liver cirrhosis, therefore other factors such as gender, age, nutrition, genetic background and additional environmental influences, particularly chronic viral infection play a role in the pathogenesis of ALD [13, 14], with the pattern of drinking (daily versus binge) and total alcohol intake (quantity and frequency) [15].

The most common and earliest response to heavy alcohol intake is the accumulation of fat, largely triglyceride (TG) in hepatocytes (steatosis), this may result from the increase of TG synthesis, inhibition of fatty acid oxidation and excessive oxidative stress [16]. Dietary fish oil such as EPA and DHA are thought to have protective effects against fatty liver. These effects are due mainly to the combined effects of inhibition of lipogenesis by inactivation of SREBP-1c and stimulation of fatty-acid oxidation by activation of PPARa in the liver. [17].

Green tea is a beverage made from natural tea leaves (Camellia sinensis) which is gaining importance around the world [18], and considered as a medicine or a healthful beverage since ancient times [19]. Epidemiologic studies suggest that GT consumption reduces serum aminotransferases, commonly used markers of liver damage. The hepatoprotective activities of GT are attributed to its catechins that scavenge ROS/RNS. Green tea also protects against oxidative stress indirectly through its hypolipidemic activities that reduce steatosis and by improving antioxidant defenses, reduces NOS expression and RNS release from macrophages. It also inhibits NADPH oxidase translocation in mast cells [20]. So this study aimed the use of omega-3 fish oil and extracts from GT for the treatment of alcohol-induced liver injury in animal model.

\section{METHODS AND MATERIALS}

\section{Animals and Housing}

In this study, 36 male albino rats of 150-200 gm in BW and 8 weeks old were used, they were housed under standard laboratory conditions, of controlled temperature $(22 \pm 4 \circ \mathrm{C})$, with about 12:12 light/dark cycles, and given standard rat diet with tap water ad libitum.

The experiment composed of 6 groups, each group with 6 rats: Group 1: negative control, Group 2: Alcoholinduced liver injury (model), Group 3: model + OMG-3 which was supplemented with (5\%) w/w in their diet and Group 4: model + GTE which was supplemented with $(1.5 \%)$ in their drinking water, Group 5: recovery group and Group 6: model + co-treatments of GTE with OMG3 oil.

\section{Green Tea extract}

Dried green tea leaves were chopped into small pieces then grinded till they became powder, then the GTE was made according to [21], by soaking $15 \mathrm{gm}$ of instant green tea powder in $1 \mathrm{~L}$ of boiling distilled water, the mixture was kept in water bath with occasional stirring for $5 \mathrm{~min}$. The solution was filtered to make $1.5 \%$ GTE. This solution was provided to rats as their sole source of drinking water.

\section{Sample collections}

At the end of the study, all rats were fasted overnight and then anesthetized with Di-ethyl ether. Blood samples were collected through cardiac puncture, placed into gel tubes $(10 \mathrm{ml})$, put in water bath $\left(37^{\circ} \mathrm{C}\right)$ for $15 \mathrm{~min}$, and finally centrifuged at $3000 \mathrm{rpm}$ for $30 \mathrm{~min}$. [22]. The serum obtained was analyzed for biochemical parameters using full-auto analyzer (cobas-311). Liver organs also separated, put in $10 \%$ formalin for histological examinations.

\section{Histological study}

The protocol used for histological study depends on [23] procedure. All liver samples were fixed in $10 \%$ formal saline, desired parts were taken by histopathologist, and then they were dehydrated through ascending concentrations of ethanol (70\%, 95\%, and 100\%), cleared in xylol, followed by infiltration and then embedded in paraffin wax. Four $\mu \mathrm{m}$ thick paraffin sections were stained by haematoxylin and eosin.

\section{RESULTS}

\section{Aspartate Aminotransferase (AST)}

Alcohol-induced liver injury rats showed significant elevation $(\mathrm{P}<0.05)$ in AST level $(198.00 \pm 5.367 \mathrm{U} / \mathrm{L})$ in comparison with their corresponding control rats (104.33 $\pm 5.719 \mathrm{U} / \mathrm{L})$.

Treatment of alcoholic rats with GT and OMG-3 both significantly lowered $(\mathrm{P}<0.05)$ serum AST activity $(169.83 \pm 7.696 \mathrm{U} / \mathrm{L})$ and $(132.67 \pm 6.103 \mathrm{U} / \mathrm{L})$ respectively when they were compared with their respective model rats. More ever co-treatments of alcohol-fed rats with GT+OMG-3 (118.50 $\pm 6.438 \mathrm{U} / \mathrm{L})$ also lowered serum AST activity significantly $(\mathrm{P}<0.05)$ when they were compared with their respective model group $(198.00 \pm 5.367 \mathrm{U} / \mathrm{L})$. Regarding the effect of time on alcohol-fed rats, it also positively affected serum AST activity $(133.83 \pm 10.694 \mathrm{U} / \mathrm{L})$ when compared with model rats. (Table $1 \&$ Figure 1 ).

\section{Alanine Aminotransferase (ALT)}

Alcohol-induced liver injury rats were associated with significant increase $(\mathrm{P}<0.05)$ in serum ALT activity $(75.50 \pm 3.507 \mathrm{U} / \mathrm{L})$ in comparison with their control rats $(47.83 \pm 1.621 \mathrm{U} / \mathrm{L})$.

Both treatments of GT, OMG-3 and their co-treatments for alcohol-fed rats lowered serum ALT activity (49.17 \pm $0.910 \mathrm{U} / \mathrm{L}),(62.17 \pm 3.085 \mathrm{U} / \mathrm{L})$ and $(50.67 \pm 2.108$ $\mathrm{U} / \mathrm{L})$ significantly $(\mathrm{P}<0.05)$ in comparison with their respective model group $(75.50 \pm 4.507 \mathrm{U} / \mathrm{L})$. The same positive effect can be seen in positive control rats which they depend on time for physiologic recovery (64.17 \pm 1.990U/L). (Table $1 \&$ Figure 2). 


\section{Alkaline Phosphatase (ALP)}

Alcohol-induced liver injury rats were associated with significant increase $(\mathrm{P}<0.05)$ in serum ALP level $(411.50$ $\pm 17.899 \mathrm{U} / \mathrm{L})$ in comparison with their respective control rats $(162.17 \pm 18.069 \mathrm{U} / \mathrm{L})$.

Treatment of alcoholic rats with OMG-3 showed no significant change $(\mathrm{P}>0.05)$ in serum ALP level (399.50 $\pm 35.286 \mathrm{U} / \mathrm{L})$, while treatment of GT $(276.33 \pm 20.939$ $\mathrm{U} / \mathrm{L})$ significantly lowered $(\mathrm{P}<0.05)$ serum ALP level in addition to co-treatments of GT+OMG-3, (203.00 \pm $22.686 \mathrm{U} / \mathrm{L})$ when they were compared with their respective model group $(411.50 \pm 17.899 \mathrm{U} / \mathrm{L})$. Furthermore, time-dependent treatment in PC group has also positive significant lowering effect $(\mathrm{P}<0.05)$ on serum ALP level $(293.17 \pm 4.308 \mathrm{U} / \mathrm{L})$ when they were compared with model rats. (Table 1 \& Figure 3 ).

\section{Serum Total Bilirubin (STB)}

Total Serum Bilirubin in alcohol-induced liver injury rats $(0.215 \pm 0.017 \mathrm{mg} / \mathrm{dL})$ were associated with significant increase $(\mathrm{P}<0.05)$ in comparison with their respective control rats $(0.166 \pm 0.010 \mathrm{mg} / \mathrm{dL})$.

Treatments for alcoholic rats with GT and OMG-3 showed significant decrease $(\mathrm{P}<0.05)$ in TSB level $(0.033 \pm 0.004 \mathrm{mg} / \mathrm{dL})$ and $(0.028 \pm 0.001 \mathrm{mg} / \mathrm{dL})$ respectively, at the same time co-treatments of, GT+OMG-3 (0.093 $\pm 0.004 \mathrm{mg} / \mathrm{dL})$ also showed significant decrease $(\mathrm{P}<0.05)$ when they were compared with their respective model group $(0.215 \pm 0.017$ $\mathrm{mg} / \mathrm{dL}$ ). Furthermore, time dependent treatment in PC group has also positive significant lowering effect $(\mathrm{P}<0.05)$ on TSB level $(0.030 \pm 0.002 \mathrm{mg} / \mathrm{dL})$ by comparing with model rats. (Table $1 \&$ Figure 4 ).

\subsubsection{Serum Albumin (ALB)}

Alcohol-induced liver injury rats were associated with no significant change $(\mathrm{P}>0.05)$ in serum ALB level $(3.280 \pm 0.123 \mathrm{gm} / \mathrm{dL})$ in comparison with their respective control rats $(3.390 \pm 0.043 \mathrm{gm} / \mathrm{dL})$.

All treatments of alcohol-induced liver injury rats with GT, OMG-3 and GT+OMG-3 (3.448 $\pm 0.111 \mathrm{gm} / \mathrm{dL})$, $(3.766 \pm 0.159 \mathrm{gm} / \mathrm{dL})$ and $(4.085 \pm 0.228 \mathrm{gm} / \mathrm{dL})$ respectively showed significant decrease $(\mathrm{P}<0.05)$ in serum ALB level in comparisons with their respective model group $(3.280 \pm 0.193 \mathrm{gm} / \mathrm{dL})$. Additionally time for positive control rats leads to significant elevation $(\mathrm{P}<0.05)$ in serum ALB level $(3.926 \pm 0.090 \mathrm{gm} / \mathrm{dL})$ when compared with model rats. (Table $1 \&$ Figure 5).

\section{Serum Total Protein (TP)}

Alcohol-induced liver injury rats were associated with significant decrease $(\mathrm{P}<0.05)$ in serum TP level $(4.808 \pm$ $0.179 \mathrm{gm} / \mathrm{dL})$ in comparison with their respective control rats $(5.801 \pm 0.114 \mathrm{gm} / \mathrm{dL})$.

The whole experiment treatments of alcoholic rats with GT, OMG-3 and GT+OMG-3 showed significant increase $(\mathrm{P}<0.05)$ in serum TP level $(6.096 \pm 0.082$ $\mathrm{gm} / \mathrm{dL}),(7.166 \pm 0.221 \mathrm{gm} / \mathrm{dL})$ and $(6.038 \pm 0.176$ $\mathrm{gm} / \mathrm{dL}$ ) respectively in comparison with their respective model group $(4.808 \pm 0.179 \mathrm{gm} / \mathrm{dL})$. The same directional effect on serum TP has been recorded by time in $\mathrm{PC}$ rats $(5.826 \pm 0.090 \mathrm{gm} / \mathrm{dL})$. (Table $1 \&$ Figure 6).
Table 1: Influence of GTE and OMG-3 on serum markers of hepatic-injury in alcohol- fed rats. (Mean \pm SE).

\begin{tabular}{|c|c|c|c|c|c|c|}
\hline Parameters & $\begin{array}{c}\text { AST } \\
(\mathbf{U} / \mathbf{L})\end{array}$ & $\begin{array}{c}\text { ALT } \\
(\mathbf{U} / \mathbf{L})\end{array}$ & $\begin{array}{c}\text { ALP } \\
(\mathbf{U} / \mathbf{L})\end{array}$ & $\underset{(\mathrm{mg} / \mathrm{dl})}{\mathrm{TB}}$ & $\underset{(\mathrm{gm} / \mathrm{dl})}{\operatorname{TP}}$ & $\underset{(\mathrm{gm} / \mathrm{dl})}{\mathrm{ALB}}$ \\
\hline \multirow[b]{2}{*}{ Negative control } & $104.33=$ & $47.83 \pm$ & $162.17 \pm$ & $0.166 \pm$ & $5.801=$ & $3.390 \pm$ \\
\hline & $5.719^{\mathbf{a}}$ & $1.621^{\mathbf{a}}$ & $18.069^{\mathbf{a}}$ & $0.010^{\mathrm{c}}$ & $0.114^{b}$ & $0.043^{\mathbf{a}}$ \\
\hline \multirow[b]{2}{*}{ Model } & $198.00=$ & $75.50=$ & $411.50=$ & $0.215=$ & $4.808=$ & $3.280=$ \\
\hline & $5.367^{\mathrm{e}}$ & $3.507 \mathrm{c}$ & $17.899^{\mathrm{C}}$ & $0.017^{d}$ & $0.179^{\mathbf{a}}$ & $0.123^{\mathrm{a}}$ \\
\hline \multirow[b]{2}{*}{ Green tea } & $169.83 \pm$ & $49.17 \pm$ & $276.33=$ & $0.033=$ & $6.096 \pm$ & $3.448 \pm$ \\
\hline & $7.696^{d}$ & $0.910^{\mathrm{a}}$ & $20.939^{b}$ & $0.004^{a}$ & $0.082^{b}$ & $0.111^{\mathrm{a}}$ \\
\hline \multirow{2}{*}{ Omega-3 } & $132.67 \pm$ & $62.17=$ & $399.50=$ & $0.028=$ & $7.166=$ & $3.766=$ \\
\hline & $6.103^{c}$ & $3.085^{b}$ & $35.286^{\mathrm{C}}$ & $0.001^{\mathbf{a}}$ & $0.221^{\mathrm{c}}$ & $0.159^{b}$ \\
\hline \multirow[b]{2}{*}{ Positive control } & $133.83 \pm$ & $64.17 \pm$ & $293.17 \pm$ & $0.030 \pm$ & $5.826 \pm$ & $3.926 \pm$ \\
\hline & $10.694^{\mathrm{c}}$ & $1.990^{\mathrm{b}}$ & $4.308^{b}$ & $0.002^{\mathrm{a}}$ & $0.107^{b}$ & $0.090 \mathrm{bc}$ \\
\hline $\begin{array}{c}\text { Green tea + } \\
\text { Omega-3 }\end{array}$ & $\begin{array}{l}118.50= \\
6.438^{b}\end{array}$ & $\begin{array}{l}50.67 \pm \\
2.108^{a}\end{array}$ & $\begin{array}{l}203.00= \\
22.686^{\mathrm{a}}\end{array}$ & $\begin{array}{l}0.093= \\
0.004 \text { b }\end{array}$ & $\begin{array}{l}6.038= \\
0.176^{b}\end{array}$ & $\begin{array}{l}4.085= \\
0.228^{\mathrm{c}}\end{array}$ \\
\hline
\end{tabular}

The same letters mean no significant differences, while the different letters mean significant difference $(\mathrm{P}<0.05)$.

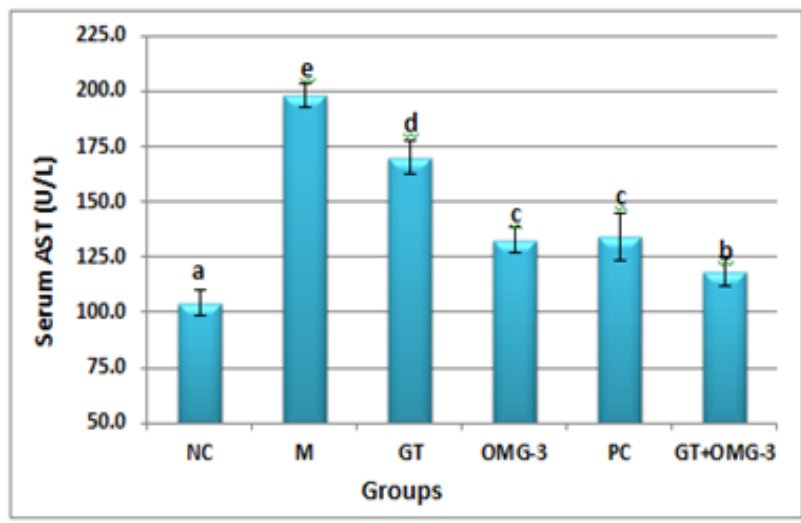

Figure 1: Influences of GTE and OMG-3 on serum AST enzyme activity in alcohol-induced liver injury rats $(\mathrm{P}<0.05)$.

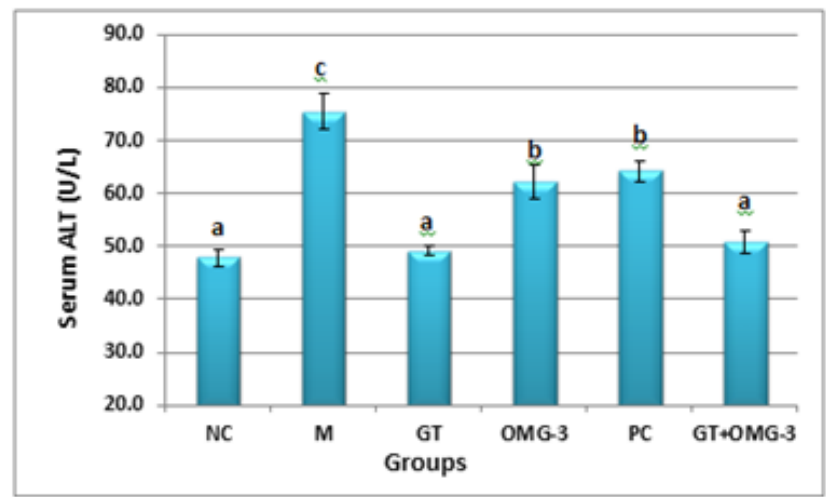

Figure 2: Influences of GTE and OMG-3 on serum ALT enzyme activity in alcohol-induced liver injury rats $(\mathrm{P}<0.05)$.

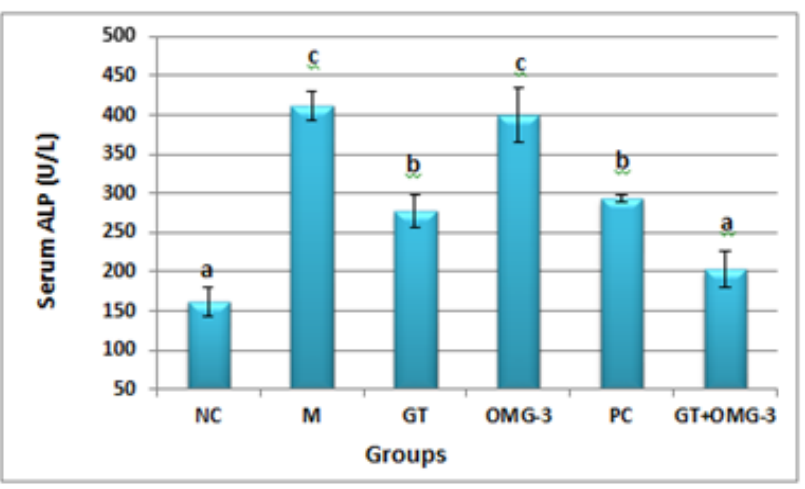

Figure 3: Influences of GTE and OMG-3 on serum ALP enzyme activity in alcohol-induced liver injury rats. $(\mathrm{P}<0.05)$. 


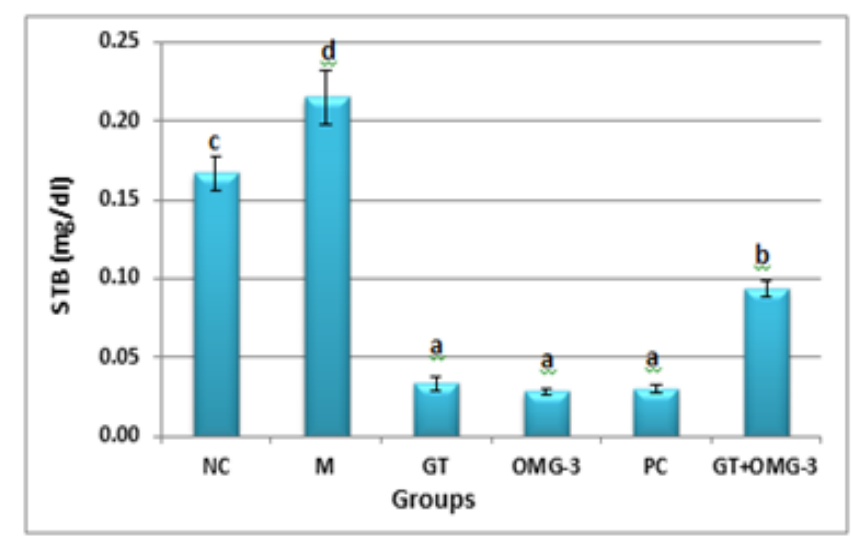

Figure 4: Influences of GTE and OMG-3 on serum STB level in alcohol-induced liver injury rats. $(\mathrm{P}<0.05)$.

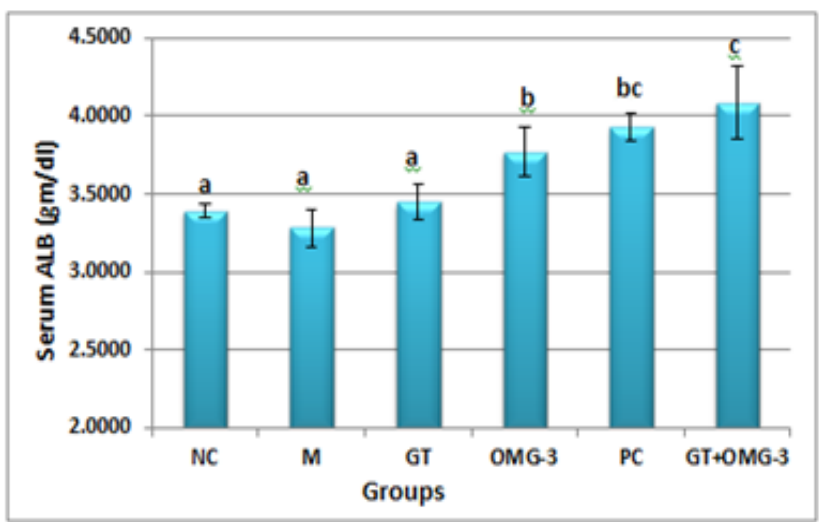

Figure 5: Influences of GTE and OMG-3 on serum ALB concentration in alcohol-induced liver injury rats $(\mathrm{P}<0.05)$.

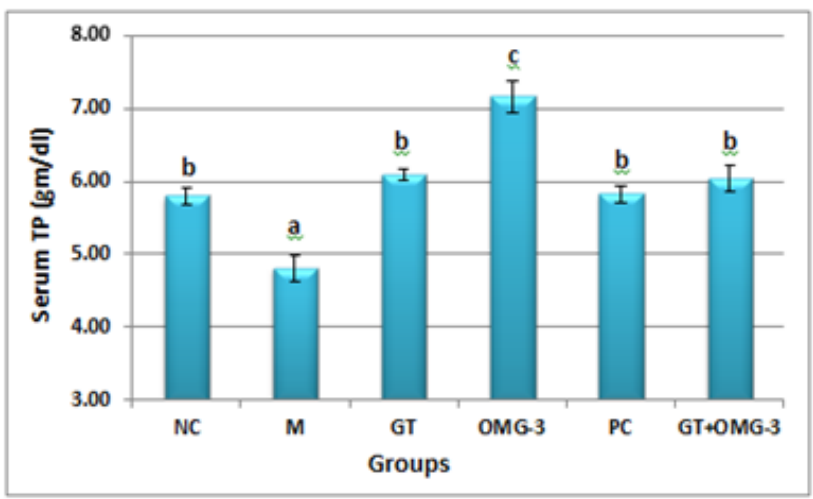

Figure 6: Influences of GTE and OMG-3 on serum TP concentration in alcohol-induced liver injury rats $(\mathrm{P}<0.05)$.

\section{Lipid Profile and Malondialdehyde (MDA)}

\section{Serum Total Cholesterol (TC)}

Alcohol-induced liver injury rats were showed a significant increase $(\mathrm{P}<0.05)$ in serum TC level $(62.17 \pm$ $2.358 \mathrm{mg} / \mathrm{dL}$ ) when they were compared to their corresponding control group $(46.50 \pm 1.232 \mathrm{mg} / \mathrm{dL})$.

All treatments for alcoholic rats either alone or in combinations like GT, OMG-3 and GT+OMG-3 lowered serum TC level significantly $(\mathrm{P}<0.05) \quad(50.50 \pm 1.432$ $\mathrm{mg} / \mathrm{dL}),(47.17 \pm 2.626 \mathrm{mg} / \mathrm{dL})$ and $(37.83 \pm 2.120$ $\mathrm{mg} / \mathrm{dL}$ ) respectively when they were compared with their respective model group $(62.17 \pm 2.358 \mathrm{mg} / \mathrm{dL})$. The time shows no significant $(\mathrm{P}>0.05)$ effect on serum TC level in alcoholic rats $(65.00 \pm 2.082 \mathrm{mg} / \mathrm{dL})($ Table $2 \&$ Figure 7).

\section{Serum Triglyceride (TG)}

Alcohol-fed rats were showed a significant increase $(\mathrm{P}<0.05)$ in serum TG level $(106.0 \pm 12.482 \mathrm{mg} / \mathrm{dL})$ in comparison with their corresponding control group $(69.00 \pm 5.698 \mathrm{mg} / \mathrm{dL})$.

All treatments for alcoholic rats either alone or in combinations with GT, OMG-3 and GT+OMG-3 significantly lowered $(\mathrm{P}<0.05)$ serum TG level $(46.00 \pm$ $6.962 \mathrm{mg} / \mathrm{dL}),(66.83 \pm 8.408 \mathrm{mg} / \mathrm{dL}),(41.83 \pm$ $6.605 \mathrm{mg} / \mathrm{dL})$ respectively when they were compared with their respective model group $(106.0 \pm 12.482$ $\mathrm{mg} / \mathrm{dL}$ ). The time without treatment shows no significant $(\mathrm{P}>0.05)$ effect on serum TG level $(51.33 \pm 2.552$ $\mathrm{mg} / \mathrm{dL}$ ) in alcoholic rats (Table $2 \&$ Figure 8).

\section{Serum High-Density Lipoprotein Cholesterol (HDL- C)}

Alcohol-induced liver injury rats were showed a significant decrease $(\mathrm{P}<0.05)$ in serum HDL-C level $(26.783 \pm 1.713 \mathrm{mg} / \mathrm{dL})$ in comparison with their respective control rats $(51.083 \pm 1.001 \mathrm{mg} / \mathrm{dL})$.

The treatments of alcoholic rats with GT and OMG-3 significantly increased $(\mathrm{P}<0.05)$ serum HDL-C level $(35.500 \pm 1.335 \mathrm{mg} / \mathrm{dL})$ and $(36.333 \pm 2.319 \mathrm{mg} / \mathrm{dL})$ respectively, in addition to GT+OMG-3 co-treatments $(50.033 \pm 2.269 \mathrm{mg} / \mathrm{dL})$ when they were compared with model group $(26.783 \pm 1.713 \mathrm{mg} / \mathrm{dL})$. Positive control rats showed significant elevation $(\mathrm{P}<0.05)$ in serum HDL-C level $(33.333 \pm 2.290 \mathrm{mg} / \mathrm{dL})$ when they were compared with model rats (Table $2 \&$ Figure 9).

\section{Serum Low-Density Lipoprotein Cholesterol (LDL- C)}

Serum LDL-C in alcohol-induced liver injury rats significantly $(\mathrm{P}<0.05)$ elevated $(21.467 \pm 1.3630 \mathrm{mg} / \mathrm{dL})$ in comparison with their corresponding control rats $(14.083 \pm 1.363 \mathrm{mg} / \mathrm{dL})$.

Treatment of alcoholic rats with GT $(19.917 \pm 5.575$ $\mathrm{mg} / \mathrm{dL})$ showed no significant change $(\mathrm{P}<0.05)$, while OMG-3 treatment showed a significant decrease $(\mathrm{P}<0.05)$ in serum LDL-C concentration $(15.933 \pm 0.634$ $\mathrm{mg} / \mathrm{dL}$ ) when they were compared with alcohol-fed group $(21.467 \pm 1.3630 \mathrm{mg} / \mathrm{dL})$.

The co-treatments of alcoholic rats with GT+OMG-3 significantly $(\mathrm{P}<0.05)$ lowered serum LDL-C level $(15.183 \pm 0.647 \mathrm{mg} / \mathrm{dL})$ when they were compared with alcohol-fed group $(51.333 \pm 2.290 \mathrm{mg} / \mathrm{dL})$, while Positive control rats $(22.233 \pm 0.930 \mathrm{mg} / \mathrm{dL})$ shows no significant effect $(\mathrm{P}>0.05)$ (Table $2 \&$ Figure 10).

\section{Serum Malondialdehyde (MDA)}

A significant increase $(\mathrm{P}<0.05)$ in serum MDA level can be seen in alcohol-induced liver injury rats (3.917 \pm $0.101 \mu \mathrm{mol} / \mathrm{l})$ in comparison with their respective control rats $(1.667 \pm 0.055 \mu \mathrm{mol} / \mathrm{l})$.

All treatments of alcoholic rats either alone or in a cotreatment method with GT, OMG-3 and GT+OMG-3 showed significant decrease $(\mathrm{P}<0.05)$ in serum MDA level $(2.667 \pm 0.172 \mu \mathrm{mol} / \mathrm{l}),(1.750 \pm 0.202 \mu \mathrm{mol} / \mathrm{l})$ and $(1.367 \pm 0.215 \mu \mathrm{mol} / \mathrm{l})$ respectively when they were compared with their respective model group (51.333 \pm 
$2.290 \mathrm{mg} / \mathrm{dL})$. In addition, the time dependent recovery $(2.917 \pm 0.186 \mu \mathrm{mol} / \mathrm{l})$ positively affected serum MDA level in alcohol abstinence group, if they were compared with model rats (Table $2 \&$ Figure 11).

Table (4-2): The protective roles of GTE and OMG-3 oil on serum lipid profiles and MDA in alcohol-fed rats. (Mean \pm SE).

\begin{tabular}{|c|c|c|c|c|c|}
\hline Groups & $\underset{(\mathrm{mg} / \mathrm{dL})}{\mathrm{TC}}$ & $\underset{(\mathrm{mg} / \mathrm{dL})}{\mathrm{TG}}$ & $\begin{array}{l}\text { HDL-C } \\
(\mathrm{mg} / \mathrm{dL})\end{array}$ & $\begin{array}{l}\text { LDL-C } \\
(\mathrm{mg} / \mathrm{dL})\end{array}$ & $\underset{(\mu \mathrm{mol} / \mathrm{h})}{\mathrm{MDA}}$ \\
\hline Negative control & $\begin{array}{l}46.50 \mathrm{z} \\
1.232^{\mathrm{b}}\end{array}$ & $\begin{array}{l}69.00 \mathrm{z} \\
5.698 \mathrm{~b}\end{array}$ & $\begin{array}{l}51.083= \\
1.001^{c}\end{array}$ & $\begin{array}{l}14.083= \\
1.363 \mathrm{a}\end{array}$ & $\begin{array}{l}1.667 \pm \\
0.055 \mathrm{a}\end{array}$ \\
\hline Model & $\begin{array}{l}62.17= \\
2.358 \mathrm{c}\end{array}$ & $\begin{array}{l}106.0= \\
12.482^{c}\end{array}$ & $\begin{array}{l}26.783= \\
1.713=\end{array}$ & $\begin{array}{l}21.467 \pm \\
0.557^{\mathrm{c}}\end{array}$ & $\begin{array}{l}3.917 \pm \\
0.101 \mathrm{c}\end{array}$ \\
\hline Green tea & $\begin{array}{l}50.50 \pm \\
1.432 \mathrm{~b}\end{array}$ & $\begin{array}{l}46.00= \\
6.962 \mathrm{ab}\end{array}$ & $\begin{array}{l}35.500= \\
1.335 \mathrm{~b}\end{array}$ & $\begin{array}{l}19.917 \pm \\
0.575^{c}\end{array}$ & $\begin{array}{l}2.667 \pm \\
0.172 \mathrm{~b}\end{array}$ \\
\hline Omega-3 & $\begin{array}{l}47.17 \pm \\
2.626^{b}\end{array}$ & $\begin{array}{l}66.83 \pm \\
8.408^{b}\end{array}$ & $\begin{array}{l}36.333= \\
2.319^{b}\end{array}$ & $\begin{array}{l}15.933= \\
0.634^{b}\end{array}$ & $\begin{array}{l}1.750= \\
0.202\end{array}$ \\
\hline Positive control & $\begin{array}{l}65.00= \\
2.082^{c}\end{array}$ & $\begin{array}{l}51.33 \pm \\
2.552^{\text {ab }}\end{array}$ & $\begin{array}{l}33.333= \\
2.290^{b}\end{array}$ & $\begin{array}{l}22.233= \\
0.930^{c}\end{array}$ & $\begin{array}{l}2.917 \pm \\
0.186^{\mathbf{b}}\end{array}$ \\
\hline $\begin{array}{c}\text { Green tea }+ \\
\text { Omega-3 }\end{array}$ & $\begin{array}{l}37.83= \\
2.120^{\mathrm{a}}\end{array}$ & $\begin{array}{l}41.83= \\
6.605 \mathrm{a}\end{array}$ & $\begin{array}{l}50.033= \\
2.269^{\mathrm{C}}\end{array}$ & $\begin{array}{l}15.183 \mathrm{a} \\
0.647^{\mathrm{ab}}\end{array}$ & $\begin{array}{l}1.367 \pm \\
0.215^{a}\end{array}$ \\
\hline
\end{tabular}

The same letters mean no significant differences while the different letters mean significant differences $(\mathrm{P}<0.05)$.

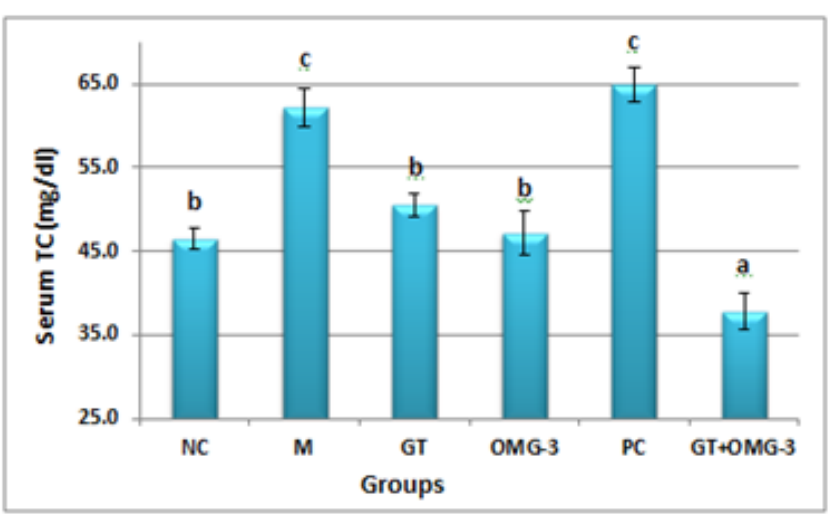

Figure (4.7): The effects of GTE and OMG-3 on serum TC level in alcohol-induced liver injury rats. $(\mathrm{P}<0.05)$

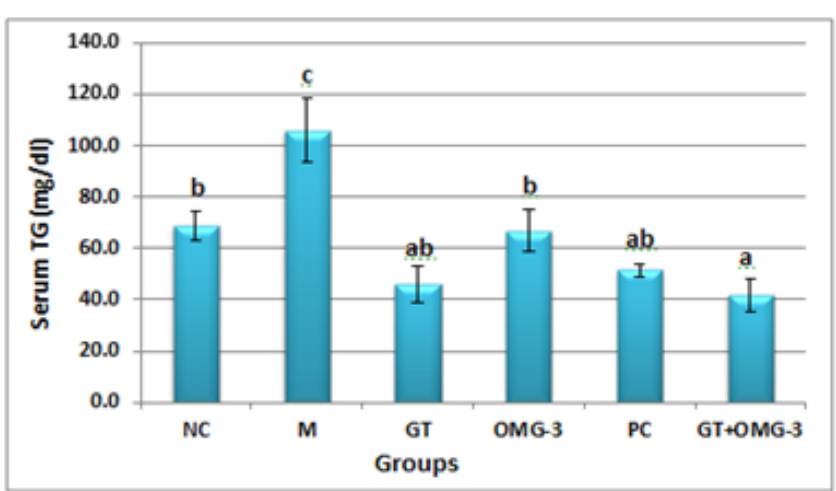

Figure (4.8): The effects of GTE and OMG-3 on serum TG level in alcohol-induced liver injury rats. $(\mathrm{P}<0.05)$

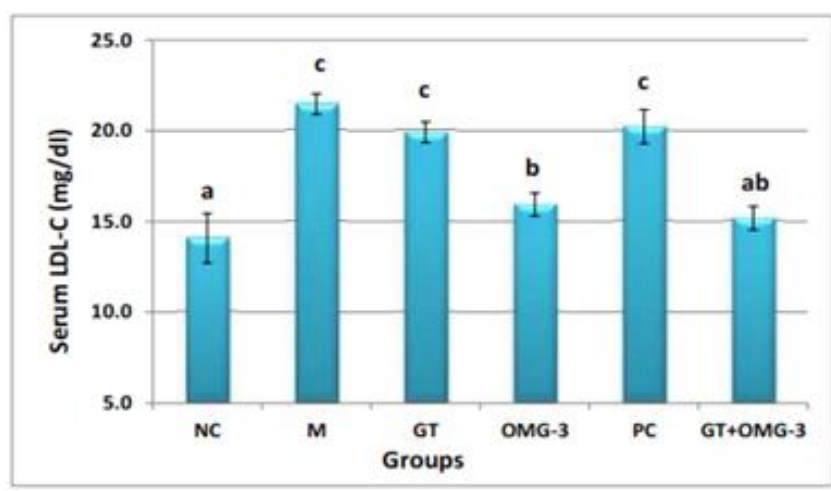

Figure 9: The effects of GTE and OMG-3 on serum HDL-C alcohol-induced liver injury rats. $(\mathrm{P}<0.05)$.

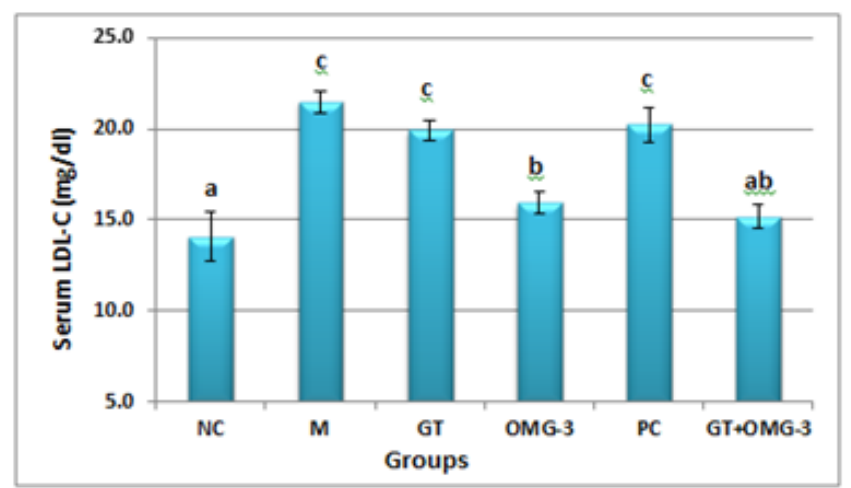

Figure 10: The effects of GTE and OMG-3 on serum LDL-C in alcohol-induced liver injury rats. $(\mathrm{P}<0.05)$.

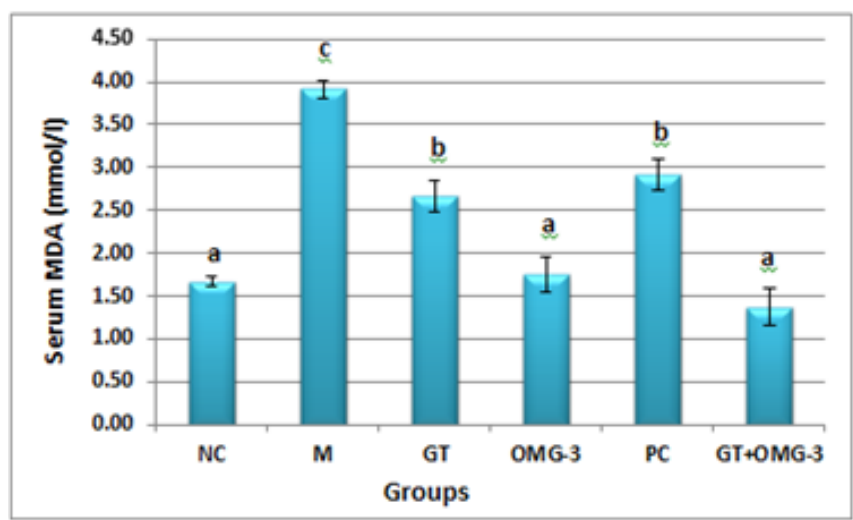

Figure 11: The effects of GTE and OMG-3 on serum MDA in alcohol-induced liver injury rats. $(\mathrm{P}<0.05)$.

\section{Histopathological changes in liver tissues}

The histopathological examination of the liver showed a clear difference between the control and alcohol-induced liver injury rats. The results from $\mathrm{H} \& \mathrm{E}$ staining assay showed that the livers from control group showed structural intactness and normal architecture towards the periphery (Figure 12) from the central vein without any impaired progression.

Conversely, ethanol intoxication causes the pathological changes in the livers of model rats including fatty change or fat deposition (microvesicular steatosis), mild multifocal hydropic degenerative change, mild portal tract inflammation, venous blood congestion, dilation of blood sinusoids, swelling of hepatocytes (hypertrophy), shrunken of hepatocytes with condensed nuclei, hyper eosinophilia and inflammation (Figure 13). 

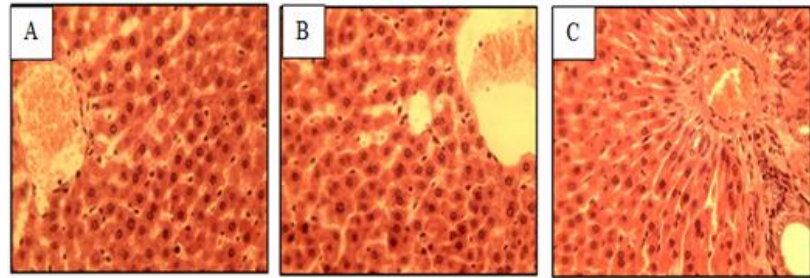

Figure 12: Liver histological features of normal control rats (A) central vein with normal texture, (B) central area and (C) Portal area (including bile duct, hepatic artery and portal vein) (H\&E staining of liver tissues, $5 \mu \mathrm{m}$ thick and 40x MP).
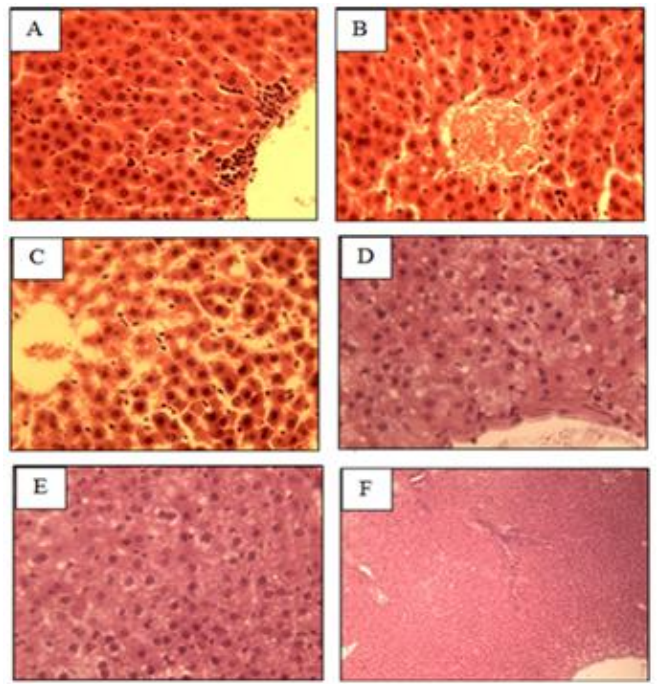

Figure (4.13): Liver histopathological changes in alcoholic rats; (A) Inflammatory cells adjacent to vein, (B) central vein congested with blood, (C) dilation of blood sinusoids, (D) hepatic cell degeneration (Swelling \& shrunken), (E) Fatty change and (F) Inflammation (10x).(H\&E staining of liver tissue, $5 \mu \mathrm{m}$ thick, 40x MP).

\section{DISCUSSION}

\section{Effects of GTE and Omega-3 on liver injury biomarkers}

The present study indicated that ethanol administration caused injury to the livers of alcohol-fed rats. This is confirmed by the results obtained from enzymatic markers of liver injury. Alcohol caused significant elevation in the levels of serum AST, ALT, ALP and TSB with significant decrease in the TP level; these findings are in agreement with previous studies conducted by $[24,25,26,3,27,28,29 \& 30]$. On the other hand serum ALB level showed no significant change, this is inconsistent with [24] who showed significant decrease in serum ALB level in rats.

Enzymatic activities ALT and AST have long been considered as a sensitive indicator of hepatic injury [24 $\&$ 31]. They are linking carbohydrate and amino acid metabolism [32]; catabolize amino acids, allowing them to enter into the citric acid [33]. Damage to the liver after ethanol ingestion is a well-known phenomenon, and the obvious sign of hepatic injury is the leakage of cellular enzymes into the plasma [24]. In this study the increased levels of serum enzymes such as AST, ALT and ALP have been observed in alcohol administered rats, which indicate the increased permeability and damage of hepatocytes.
[34] stated that hyper-bilirubinemia in alcohol-fed rats may be a result of releasing unconjugated bilirubin from damaged and dead hepatocytes which is a chemical break-down product of hemoglobin that conjugated with glucuronic acid in hepatocytes to increase its water stability. At the same way increasing the TSB level indicated a reduction in the excretory capability of the liver as a consequence of liver injury [35].

According to [36] significant change in serum TP by alcohol ingestion probably indicate that the buffering capacity of the blood has been enhanced through impairment in the normal functions of the liver, insignificant change in serum albumin level could indicate that serum levels of metals, ions, fatty acids and amino acids has not been compromised.

In treatment study of the current work treatments of alcoholic rats with GT and OMG-3 alone or in combinations positively lowered the levels of serum enzymatic markers of liver injury (AST, ALT and ALP) and STB when they were compared to their corresponding model group, except for OMG-3 treatment on ALP enzyme which is shows no significant change. These results were in accordance with previous studies carried out by [37, 38, 39, 40, $41 \& 42]$.

Green tea, a popular beverage in Asia, is continually reported to have a wide range of health benefits, including anti-inflammation, anti-oxidative and immunestimulating effects [43]. The protective effect of green tea is connected with its components called flavonoids which possess scavenging free radical properties [21]. The current study revealed that aqueous GTE have a potential role in stabilizing plasma membrane as well as repairing hepatic tissue damage and improvement of liver function caused by alcohol, as it is confirmed by the results obtained in serum transaminase enzymes and TSB levels. The results of the present study strongly suggest that GTE protects against oxidative damage to hepatic tissue by preventing excessive lipid peroxidation and by maintaining serum hepatic marker enzymes, TP, and ALB of alcoholic rats near normal concentrations.

[34] described that treated NAFLD patients with EPA reduce serum ALT and AST concentrations when compared with patients who refused EPA supplementation. Interestingly, liver perfusion was also improved by EPA, perhaps reflecting an enhancement of hepatic microcirculatory function. In most cases, the improvement in bilirubin concentration was rapid and reached a normal level, whereas ALP concentration was not significantly decreased during the first 4 weeks after initiating therapy with omegaven [19], regarding STB and ALP, this agrees with the results of our study.

Analysis of our data showed that administration of OMG-3 fish oil to alcohol-fed rats resulted in a significant increase in serum TP and ALB levels, these findings were in agreement with [41] who studied hepatoprotective activity of omega-3 fish oil against thioacetamide-induced fibrosis in rats. In addition [42], demonstrated that the increase in concentration of serum TP and ALB within the normal range in rabbits fed on economic control diet supplemented with 0.5 and $1.0 \mathrm{~mL}$ fish oil per day $/ \mathrm{kg}$ live bodyweight may reflect an increase in the hepatic function when animals were fed on fish oil. 
Albumin, the most abundant plasma metal-binding protein, is an important extra cellular antioxidant regulating glutathione levels in lungs epithelial cells, shown to possess free radical scavenging properties. Therefore, significantly raised albumin is important as it may scavenge reactive oxygen species [1].

\section{Effects of GTE and omega-3 on serum lipid profile and MDA}

As [7] mentioned, one of the best known biological effects of heavy ethanol consumption is the production of fatty liver and hyper lipidemia. In addition, [44] also reported the same observations in humans and rodents. The molecular mechanisms beyond this action cited by [45], which explained that alcohol can disturb lipid metabolism through modulating lipogenic gene expression. Moreover, [29] similarly indicated that lipid homeostasis in vertebrate cells is regulated by a family of membrane-bound transcription factors designated SREBPs, which regulate fatty acid, triglyceride and cholesterol synthesis. In vivo, SREBP-2 preferentially activates the genes of cholesterol metabolism, whereas SREBP-1 specially activates the genes of fatty acid and TG metabolism in the liver and most other intact tissues. Finally PPAR- $\alpha$ can activate both fatty acid oxidation and export; thereby it protects against the accumulation of TG, improves the enzymatic defenses against oxidative stress. Furthermore, [45] mentioned that chronically feeding alcohol to rodents resulted in a significant increase in the SREBP-1c level, which in turn elevates fatty acid synthesis in hepatocytes via upregulation of SREBP-1c and its downstream lipogenic genes.

One of the mechanisms by which alcohol is proposed to mediate its toxic effects is through oxidative stress and oxidative damage due to an increased production of ROS which characterized by increasing the products of lipid peroxidation [46]. This is improved by the current study in which the levels of serum MDA significantly elevated in alcohol-treated rats. The same results approved by earlier studies like [2 \& 47]. This data is directly proportional to those results obtained on HDL-C and LDL-C by this study, which it plays a major role in the mobilization of lipids between body tissues and peripheral blood.

The study treatment of GT and OMG-3 even in their combinations mode improved the levels of serum TC, TG, LDL-C and MDA concentration. These improvement effects of GTE and OMG-3 oil were also confirmed by previous studies such as $[48,49,50,32 \&$ 51].

Malondialdehyde is a major reactive aldehyde, resulting from the peroxidation of biological membranepolyunsaturated fatty acid, used as an indicator of tissue damage [32]. [32] documented that GTE inhibiting hepatic lipid peroxidation, usually by suppressing adipose lipogenic activities and maintains body with proper lipid metabolism, in [47] mentioned that giving GT simultaneously with ethanol to rats resulted in normalization of lipid peroxidation process by the action of catechins which are water-soluble antioxidants that reduce the mobility of the free radicals into the lipid bilayer as well.
[49] Stated that PUFAs, particularly those from the OMG-3 family, increase the fatty acid oxidative capacity of tissues through their ability to function as ligand activators of PPAR- $\alpha$ and thereby induce transcription of several gene-encoding proteins affiliated with fatty acid oxidation. These data are consistent with [52] who explained that OMG-3 fatty acids exert potential hypocholesterolemic effect through inhibition of key enzymes related to cholesterol synthesis and transfer such as 3-Hydroxy-3-methylglutaryl reductase and acylCoA: cholesterol acyltransferase and selectively lower triglycerides by increasing glucose flux to glycogen, increasing mitochondrial $\beta$-oxidation, and decreasing triglycerides synthesis, an effect that is mediated partially by PPAR-a activation.

Furthermore; [53] revealed that NEFAs are substrate for TG synthesis and suggested that the TG lowering effect of n-3 PUFA could be due to an increased stimulation of $\beta$-oxidation, which leads to a decrease in available NEFA for TG formation. They also stated that HDL-2 and HDL-3 are the most characterized HDL subclasses, and HDL-2 involved in scavenging more cholesterol from the peripheral tissues compared to HDL-3. Omega3 PUFA has been shown to increase the concentration of HDL-2 particles; even without obvious change in total HDL concentration. OMG-3 fatty acid supplementation has free radical scavenger activity, it may also stimulate vitamin $\mathrm{E}$ incorporation into membranes to avoid lipid peroxidation and ROS resulting from increased membrane omega-3 fatty acid treatment, hence omega-3 could be a potential treatment for oxidative stress [54].

\section{Effects of GTE and omega-3 on liver histopathology}

Findings of the current study from histopathological analyses of liver revealed that ethanol-treated rats experienced microvesicular steatosis, mild multifocal hydropic degenerative change, mild portal tract inflammation, venous blood congestion, dilation of blood sinusoids, swelling of hepatocytes (hypertrophy), shrunken of hepatocytes with condensed nuclei, hyper eosinophilia and inflammation in comparisons with normal controls which showed structural intactness and normal histologic architecture. This finding corroborates with previous findings [55, 56, 11, 12 \& 23]. The marked fatty changes in the hepatic tissue correlated with the abnormal biochemical parameters observed in the present study.

Steatosis; accumulation of lipids in the hepatocytes, is the most striking initial manifestation of alcohol-induced liver injury which are highly sensitive to further alcoholic insult leading to the development of more severe manifestations of alcohol-induced liver diseases such as hepatitis, fibrosis, cirrhosis and eventually hepatocellular carcinoma [50]. Upregulation of sterol regulatory element-binding protein (SREBP)-1c is one of the mechanisms in the development of steatosis [57]. Whereas [58] belonged this to that alcohol is rich in calories and devoid of nutrients, thus contributing to lipid accumulation in the liver.

The histological observations of the current study basically supported the demonstrated results obtained from the serum enzyme assays and lipid profiles. The alcohol treatment induced the marked accumulation of lipid droplet in the numbers and volumes in the 
hepatocytes as fatty liver progression. In addition, [44] previously reported that fatty change could be explained on the basis that alcohol ingestion induced a pronounced increase in $\mathrm{NADH} / \mathrm{NAD}+$ ratio, leading to increased concentration of glycerol-3-phosphate which favors triglycerides synthesis and accelerates their hepatic accumulation.

Fortunately, the fatty liver is a reversible condition [59]. Although results of the biochemical assays of the current study are important for investigating the improvement effects of GTE and OMG-3 fish oil on ethanol induced liver injury, the external investigation of the hepatic histopathologic changes were also carried out.

The present study clearly confirmed that the treatment of alcohol-fed rats with GTE and OMG-3 oil exhibited beneficial effects both in their combinations and separately. The same results were approved by earlier studies including [17, 37, 60, $21 \& 40]$.

The mechanisms underlying the hepatoprotective effects of omega-3 fatty acids are not completely understood. [17] indicate that habitual intake of fish oil prevents development of fatty liver in response to ethanol consumption. The molecular mechanism by which small amounts of DHA/AA exert their protective effects against liver steatosis is poorly understood. A PUFA diet may decrease the rates of fat biosynthesis while it increases the fat transport and degradation. In addition, these PUFAs may restore the expression of the PPAR- $\alpha$, whose expression is dys-regulated by ethanol [61].

Lipid peroxidation due to ROS production during ethanol oxidation favors lipid accumulation in hepatocytes [62, $37 \& 47]$ documented that GTE could markedly decrease hepatic fatty changes through protection against oxidative damage and suppressing SREBP-1 maturation, and hence, lipogenesis in the liver. Also [32] reported that GT is an excellent source of acidic polysaccharides including neutral rhamnose, arabinose, fucose, xylose, mannose, glucose and galactose in a molar percent, which are able to confer a strong protection against the hepatic damage via the activation of the hepatic antioxidant system and the reversal of lipid peroxidation. Finally, [60] stated that omega-3 FAs exert an inhibitory effect on hepatic FA synthesis and stimulate hepatic lipolysis.

In general, it should be noted that most of the physiological responses for any treatment on experimental animals have dose- and time-dependent properties. This also could be applied on the current study during the induction of liver injury or recovery part. In this study; although different doses were not carried out among groups, the physiologic autorecovering capacity of experimental rats were studied which depending on time without any treatment after they were exposed to liver injury.

It should also be noted that time-dependent recovery in the current study showed positive effect for most parameters especially for HDL-C, TSB and TP which they were closed to their baseline records after the period of four weeks. This could indicate that body homeostasis always help to normalize physiological disorders. On the other hand, more significant improvement or rapid amelioration can be seen when physiologic treatments were used for the same duration. Furthermore, current study showed that combinations of GT and OMG-3 have more positive or stronger physiologic effect on alcoholinduced liver injury in almost all parameters than their treatments alone, according to [63] this may due to their greater bioavailability together than their treatments alone, this is well sensed in LFT parameters of the current study which are showing the liver either functions properly or not.

\section{CONCLUSIONS}

The results of the present study could draw the following conclusions:

1. Ethanol consumption can impair hepatic functions, which associated with significant increase in serum AST, ALT, ALP and TSB with significant decrease of serum TP, but failed to make significant change of serum ALB.

2. Ethanol intoxication markedly disturb lipid metabolism, induced-hyperlipidemia and increased oxidative stress.

3. Alcohol abuse has no significant effect on WBC, PLT, MCH, MCHC and MCV while parameters of body oxygen suppliers (RBC, HCT and HGB) increased.

4. Administration of alcohol alters histologic patterns of liver tissue; most noticeably induce fatty liver (Steatosis), mild hepatocyte degeneration, blood congestion and dilation of hepatic blood sinusoids.

5. Aqueous extracts of GT and OMG-3 oil significantly prevent and improve alcoholinduced liver injury through improvement of serum markers of hepatic injury, their hypolipidemic actions and hepatic histologic recovery.

6. Co-treatments of GT+OMG-3 have more protective effect or faster progression against ALD than their treatments alone.

7. Alcohol abstinence help to recover the damaged effects of alcohol consumption according to the time, but faster retrains or more effective results obtained when GT or OMG-3 were administered at the same time.

8. Most significant improvement effect on lipid profile and serum MDA level were shown by omega-3, whereas most effective histologic action recorded by GTE treatment.

\section{REFERENCE}

[1] P. Yao, K. Li, Y. Jin, F. Song, S. Zhou, X. Sun, A. Nüssler and L. Liu, "Oxidative damage after chronic ethanol intake in rat tissues: Prophylaxis of Ginkgo biloba extract", Food Chemistry, vol. 99, no. 2, pp. 305-314, 2006.

[2] H. Park, S. Ha, H. Eom and I. Choi, "Narirutin fraction from citrus peels attenuates alcoholic liver disease in mice", Food and Chemical Toxicology, vol. 55, pp. 637-644, 2013.

[3] A. Dey and A. Cederbaum, "Alcohol and oxidative liver injury", Hepatology, vol. 43, no. 1, pp. S63-S74, 2006.

[4] P. Calder, "Marine omega-3 fatty acids and inflammatory processes: Effects, mechanisms and clinical relevance", Biochimica et Biophysica Acta (BBA) - Molecular and Cell Biology of Lipids, vol. 1851, no. 4, pp. 469-484, 2015.

[5] H. Erdogan, E. Fadillioglu, S. Ozgocmen, S. Sogut, B. Ozyurt, O. Akyol and O. Ardicoglu, "Effect of fish oil supplementation on plasma oxidant/antioxidant status in rats", Prostaglandins, Leukotrienes and Essential Fatty Acids, vol. 71, no. 3, pp. 149$152,2004$. 
[6] E. Hodgson, A textbook of modern toxicology. Hoboken, New Jersey: Wiley, 2015.

[7] S. Ki, J. Choi, C. Kim and S. Kim, "Combined metadoxine and garlic oil treatment efficaciously abrogates alcoholic steatosis and CYP2E1 induction in rat liver with restoration of AMPK activity", Chemico-Biological Interactions, vol. 169, no. 2, pp. 80-90, 2007.

[8] J. Lee, T. Oh, Y. Kim, J. Baik, S. So, K. Hahm and Y. Surh, "Protective effects of green tea polyphenol extracts against ethanol-induced gastric mucosal damages in rats: Stressresponsive transcription factors and MAP kinases as potential targets", Mutation Research/Fundamental and Molecular Mechanisms of Mutagenesis, vol. 579, no. 1-2, pp. 214-224, 2005.

[9] A. Dasgupta and A. Wahed, Clinical chemistry, immunology and laboratory quality control.

[10] P., Bigoniya. Singh C. S., and A. Shukla. "A comprehensive review of different liver toxicants used in experimental pharmacology." International Journal of Pharmaceutical Sciences and Drug Research 1.3 124-135, 2009.

[11] M. Choi, J. Han, H. Kim, J. Lee, J. Lee, J. Wang, S. Son, H. Park and C. Son, "Aqueous extract of Artemisia capillaris exerts hepatoprotective action in alcohol-pyrazole-fed rat model", Journal of Ethnopharmacology, vol. 147, no. 3, pp. 662-670, 2013.

[12] M. Li, Y. Lu, Y. Hu, X. Zhai, W. Xu, H. Jing, X. Tian, Y. Lin, D. Gao and J. Yao, "Salvianolic acid B protects against acute ethanol-induced liver injury through SIRT1-mediated deacetylation of p53 in rats", Toxicology Letters, vol. 228, no. 2, pp. 67-74, 2014.

[13] A. Singal and S. Jampana, "Current Management of Alcoholic Liver Disease", Current Drug Abuse Reviews, vol. 7, no. 1, pp. 18-28, 2014.

[14] S. O'shea, D. Srinivasan, and J. Arthur. McCullough. "Alcoholic liver disease." Hepatology 51, no. 1: 307-328, 2010.

[15] S. Zakhari and T. Li, "Determinants of alcohol use and abuse: Impact of quantity and frequency patterns on liver disease", Hepatology, vol. 46, no. 6, pp. 2032-2039, 2007.

[16] Ki, J. Choi, C. Kim and S. Kim, "Combined metadoxine and garlic oil treatment efficaciously abrogates alcoholic steatosis and CYP2E1 induction in rat liver with restoration of AMPK activity", Chemico-Biological Interactions, vol. 169, no. 2, pp. 80-90, 2007.

[17] S. Wada, T. Yamazaki, Y. Kawano, S. Miura and O. Ezaki, "Fish oil fed prior to ethanol administration prevents acute ethanol-induced fatty liver in mice", Journal of Hepatology, vol. 49, no. 3, pp. 441-450, 2008.

[18] C. Chengelis, J. Kirkpatrick, K. Regan, A. Radovsky, M. Beck, O. Morita, Y. Tamaki and H. Suzuki, "28-Day oral (gavage) toxicity studies of green tea catechins prepared for beverages in rats", Food and Chemical Toxicology, vol. 46, no. 3, pp. 978-989, 2008.

[19] D. Abdulzahra, and A. Razzak, "The Possible Protective Effect of Green Tea Extract against Methotrexate-Induced Liver Injury in Male Rats", Medical Journal of Babylon, vol. 9(3), pp. 650-655, 2012

[20] M. Chung, H. Park, J. Manautou, S. Koo and R. Bruno, "Green tea extract protects against nonalcoholic steatohepatitis in ob/ob mice by decreasing oxidative and nitrative stress responses induced by proinflammatory enzymes", The Journal of Nutritional Biochemistry, vol. 23, no. 4, pp. 361-367, 2012.

[21] E. Mehana, A. Meki and K. Fazili, "Ameliorated effects of green tea extract on lead induced liver toxicity in rats", Experimental and Toxicologic Pathology, vol. 64, no. 4, pp. 291-295, 2012.

[22] K. Eswar Kumar, K. Harsha, V. Sudheer and N. Giri babu, "In vitro antioxidant activity and in vivo hepatoprotective activity of aqueous extract of Allium cepa bulb in ethanol induced liver damage in Wistar rats", Food Science and Human Wellness, vol. 2, no. 3-4, pp. 132-138, 2013.

[23] H. Darwish, N. Abd Raboh and A. Mahdy, "Camel's milk alleviates alcohol-induced liver injury in rats", Food and Chemical Toxicology, vol. 50, no. 5, pp. 1377-1383, 2012

[24] R. Saravanan, P. Viswanathan and K. Pugalendi, "Protective effect of ursolic acid on ethanol-mediated experimental liver damage in rats", Life Sciences, vol. 78, no. 7, pp. 713-718, 2006.

[25] "Lipid Metabolism and Disorders", in Clinical Chemistry, Immunology and Laboratory Quality Control", 2018.
[26] M. Li, Y. Lu, Y. Hu, X. Zhai, W. Xu, H. Jing, X. Tian, Y. Lin, D. Gao and J. Yao, "Salvianolic acid B protects against acute ethanol-induced liver injury through SIRT1-mediated deacetylation of p53 in rats", Toxicology Letters, vol. 228, no. 2, pp. 67-74, 2014

[27] M. Choi, J. Han, H. Kim, J. Lee, J. Lee, J. Wang, S. Son, H. Park and C. Son, "Aqueous extract of Artemisia capillaris exerts hepatoprotective action in alcohol-pyrazole-fed rat model", Journal of Ethnopharmacology, vol. 147, no. 3, pp. 662-670, 2013

[28] J. Je, J. Cha, Y. Cho, H. Ahn, J. Lee, Y. Cho and C. Ahn, "Hepatoprotective effect of peptic hydrolysate from salmon pectoral fin protein byproducts on ethanol-induced oxidative stress in Sprague-Dawley rats", Food Research International, vol. 51 , no. 2 , pp. 648-653, 2013

[29] C. Tang, H. Huang, Y. Lee, Y. Tang and C. Wang, "Hepatoprotective effect of mulberry water extracts on ethanol-induced liver injury via anti-inflammation and inhibition of lipogenesis in C57BL/6J mice", Food and Chemical Toxicology, vol. 62, pp. 786-796, 2013.

30] H. Lee and M. Lee, "Coordinated regulation of scopoletin at adipose tissue-liver axis improved alcohol-induced lipid dysmetabolism and inflammation in rats", Toxicology Letters, vol. 237, no. 3, pp. 210-218, 2015.

[31] S. Williams, H. Shih, D. Guenette, W. Brackney, M. Denison, G. Pickwell and L. Quattrochi, "Comparative studies on the effects of green tea extracts and individual tea catechins on human CYP1A gene expression", Chemico-Biological Interactions, vol. 128, no. 3, pp. 211-229, 2000.

[32] X. Lu, Y. Zhao, Y. Sun, S. Yang and X. Yang, "Characterisation of polysaccharides from green tea of Huangshan Maofeng with antioxidant and hepatoprotective effects", Food Chemistry, vol. 141, no. 4, pp. 3415-3423, 2013.

[33] E. Mehana, A. Meki and K. Fazili, "Ameliorated effects of green tea extract on lead induced liver toxicity in rats", Experimental and Toxicologic Pathology, vol. 64, no. 4, pp. 291-295, 2012

[34] S. Meenakshi, S. Umayaparvathi, R. Saravanan, T. Manivasagam and T. Balasubramanian, "Hepatoprotective effect of fucoidan isolated from the seaweed Turbinaria decurrens in ethanol intoxicated rats", International Journal of Biological Macromolecules, vol. 67, pp. 367-372, 2014

[35] D. Abdulzahra, and A. Razzak, "The Possible Protective Effect of Green Tea Extract against Methotrexate-Induced Liver Injury in Male Rats", Medical Journal of Babylon, vol. 9(3), pp. 650-655, 2012.

[36] K.O, "Effects Of Some Alcoholic Beverages on Haematological and Plasma Biochemical Parameters in Male Albino Rats.", IOSR Journal of Pharmacy and Biological Sciences, vol. 4, no. 6, pp. 55-58, 2013.

[37] E. Ramesh, T. Jayakumar, R. Elanchezhian, M. Sakthivel, P. Geraldine and P. Thomas, "Green tea catechins, alleviate hepatic lipidemic-oxidative injury in Wistar rats fed an atherogenic diet", Chemico-Biological Interactions, vol. 180, no. 1, pp. 10-19, 2009.

[38] H. Shapiro, M. Tehilla, J. Attal-Singer, R. Bruck, R. Luzzatti and $\mathrm{P}$. Singer, "The therapeutic potential of long-chain omega3 fatty acids in nonalcoholic fatty liver disease", Clinical Nutrition, vol. 30, no. 1, pp. 6-19, 2011

[39] D. Abdulzahra, and A. Razzak, "The Possible Protective Effect of Green Tea Extract against Methotrexate-Induced Liver Injury in Male Rats", Medical Journal of Babylon, vol. 9(3), pp. 650-655, 2012.

[40] W. Chen, S. Lin, H. Pan, S. Liao, Y. Chuang, Y. Yen, S. Lin and C. Chen, "Beneficial effect of docosahexaenoic acid on cholestatic liver injury in rats", The Journal of Nutritional Biochemistry, vol. 23, no. 3, pp. 252-264, 2012.

41] N. Abo El-Magd, A. El-Karef, M. El-Shishtawy and L. Eissa, "Hepatoprotective effects of glycyrrhizin and omega-3 fatty acids on Nuclear Factor-kappa B pathway in thioacetamideinduced fibrosis in rats", Egyptian Journal of Basic and Applied Sciences, vol. 2, no. 2, pp. 65-74, 2015.

[42] W. Janczyk, D. Lebensztejn, A. Wierzbicka-Rucińska, A Mazur, J. Neuhoff-Murawska, P. Matusik and P. Socha, "Omega-3 Fatty Acids Therapy in Children with Nonalcoholic Fatty Liver Disease: A Randomized Controlled Trial", The Journal of Pediatrics, vol. 166, no. 6, pp. 1358-1363.e3, 2015.

[43] X. Lu, Y. Zhao, Y. Sun, S. Yang and X. Yang, "Characterisation of polysaccharides from green tea of 
Huangshan Maofeng with antioxidant and hepatoprotective effects", Food Chemistry, vol. 141, no. 4, pp. 3415-3423, 2013.

[44] M. Sozio and D. Crabb, "Alcohol and lipid metabolism", American Journal of Physiology-Endocrinology and Metabolism, vol. 295, no. 1, pp. E10-E16, 2008.

[45] M. Kim, M. Sim, H. Lee, J. Ham, K. Seo and M. Lee, "Dietary umbelliferone attenuates alcohol-induced fatty liver via regulation of PPAR $\alpha$ and SREBP-1c in rats", Alcohol, vol. 48, no. 7, pp. 707-715, 2014.

[46] R. Nordmann, C. Ribière and H. Rouach, "Implication of free radical mechanisms in ethanol-induced cellular injury", Free Radical Biology and Medicine, vol. 12, no. 3, pp. 219-240, 1992.

[47] J. Ostrowska, W. Łuczaj, I. Kasacka, A. Różański and E. Skrzydlewska, "Green tea protects against ethanol-induced lipid peroxidation in rat organs", Alcohol, vol. 32, no. 1, pp. 25-32, 2004.

[48] J. Jimenez-Lopez and A. Cederbaum, "Green tea polyphenol epigallocatechin-3-gallate protects HepG2 cells against CYP2E1-dependent toxicity", Free Radical Biology and Medicine, vol. 36, no. 3, pp. 359-370, 2004.

[49] C. Aguilera, C. Ramirez-Tortosa, J. Quiles, M. Yago, M. Martínez-Burgos, E. Martínez-Victoria, Á. Gil and M. Ramirez-Tortosa, "Monounsaturated and $\omega-3$ but not $\omega-6$ polyunsaturated fatty acids improve hepatic fibrosis in hypercholesterolemic rabbits", Nutrition, vol. 21, no. 3, pp. 363-371, 2005.

[50] Y. Park and J. Kang, "Korean Red Ginseng Extract Suppresses the Progression of Alcoholic Fatty Liver in a Rat Model", JOURNAL OF HEALTH SCIENCE, vol. 57, no. 6, pp. 512520, 2011.

[51] A. Zanwar, M. Hegde, S. Rojatkar and S. Bodhankar, "Antihyperlipidemic activity of concomitant administration of methanolic fraction of flax lignan concentrate and omega-3fatty acid in poloxamer-407 induced experimental hyperlipidemia", Industrial Crops and Products, vol. 52, pp. 656-663, 2014.

[52] L. Eissa, N. Abdel-Rahman, , \& M. Eraky, "Effects of omega3 fatty acids and pioglitazone combination on insulin resistance through fibroblast growth factor 21 in type 2 diabetes mellitus. Egyptian Journal of Basic and Applied Sciences, vol. 2(2), pp. 75-86, 2015.

[53] K. Balogun, R. Randunu and S. Cheema, "The effect of dietary omega-3 polyunsaturated fatty acids on plasma lipids and lipoproteins of C57BL/6 mice is age and sex specific", Prostaglandins, Leukotrienes and Essential Fatty Acids (PLEFA), vol. 91, no. 1-2, pp. 39-47, 2014.

[54] M. Karapehlivan, M. Ogun, I. Kaya, H. Ozen, H. Deveci and M. Karaman, "Protective effect of omega-3 fatty acid against mercury chloride intoxication in mice", Journal of Trace Elements in Medicine and Biology, vol. 28, no. 1, pp. 94-99, 2014

[55] H. Wang, F. Feng, B. Zhuang and Y. Sun, "Evaluation of hepatoprotective effect of Zhi-Zi-Da-Huang decoction and its two fractions against acute alcohol-induced liver injury in rats", Journal of Ethnopharmacology, vol. 126, no. 2, pp. 273279, 2009.

[56] L. Tirapelli, M. Batalhão, A. Jacob-Ferreira, D. Tirapelli, E. Carnio, J. Tanus-Santos, R. Queiroz, S. Uyemura, C. Padovan and C. Tirapelli, "Chronic ethanol consumption induces histopathological changes and increases nitric oxide generation in the rat liver", Tissue and Cell, vol. 43, no. 6, pp. 384-391, 2011

[57] C. Forsyth, A. Farhadi, S. Jakate, Y. Tang, M. Shaikh and A. Keshavarzian, "Lactobacillus GG treatment ameliorates alcohol-induced intestinal oxidative stress, gut leakiness, and liver injury in a rat model of alcoholic steatohepatitis", Alcohol, vol. 43, no. 2, pp. 163-172, 2009.

[58] J. Cha, H. Ahn, Y. Cho and J. Je, "Protective effect of cordycepin-enriched Cordyceps militaris on alcoholic hepatotoxicity in Sprague-Dawley rats", Food and Chemical Toxicology, vol. 60, pp. 52-57, 2013.

[59] M. Kang, G. Ahn, X. Yang, K. Kim, S. Kang, S. Lee, S. Ko, J. Ko, D. Kim, Y. Kim, Y. Jee, S. Park and Y. Jeon, "Hepatoprotective effects of dieckol-rich phlorotannins from Ecklonia cava, a brown seaweed, against ethanol induced liver damage in BALB/c mice", Food and Chemical Toxicology, vol. 50, no. 6, pp. 1986-1991, 2012.
[60] H. Marsman, M. Heger, J. Kloek, S. Nienhuis, F. ten Kate and T. van Gulik, "Omega-3 fatty acids reduce hepatic steatosis and consequently attenuate ischemia-reperfusion injury following partial hepatectomy in rats", Digestive and Liver Disease, vol. 43, no. 12, pp. 984-990, 2011.

[61] B. Song, K. Moon, N. Olsson and N. Salem, "Prevention of alcoholic fatty liver and mitochondrial dysfunction in the rat by long-chain polyunsaturated fatty acids", Journal of Hepatology, vol. 49, no. 2, pp. 262-273, 2008.

[62] H. Park, D. DiNatale, M. Chung, Y. Park, J. Lee, S. Koo, M. O'Connor, J. Manautou and R. Bruno, "Green tea extract attenuates hepatic steatosis by decreasing adipose lipogenesis and enhancing hepatic antioxidant defenses in ob/ob mice", The Journal of Nutritional Biochemistry, vol. 22, no. 4, pp. 393-400, 2011

[63] B. Giunta, H. Hou, Y. Zhu, J. Salemi, A. Ruscin, R. Shytle and J. Tan, "Fish oil enhances anti-amyloidogenic properties of green tea EGCG in Tg2576 mice", Neuroscience Letters, vol. 471, no. 3, pp. 134-138, 2010. 